\title{
IMPACT OF PEAT INDUSTRY DEVELOPMENT ON REGIONAL SUSTAINABILITY
}

\author{
Alexander Semin \\ Ural State Mining University, Yekaterinburg, Russia
}

\begin{abstract}
The study aimed to substantiate the nature of the interaction between the economic efficiency of the peat industry and the sustainability of the region on the example of the Khanty-Mansi Autonomous Area (KhMAA) of Russia. Based on the development indicators of the districts of KhMAA for 20172020, the factors characterizing the components of sustainable regional development were determined using the principal components' method. Using the fuzzy sets' method, the values, levels of the factors, and the integral indicator of sustainable development were calculated, and the realized and unrealized potential of peat industry development in the context of the districts of the study area were determined. The causal relationships between indicators of regional sustainable development and peat industry potential, and the nature of dependence between the indicators, are argued. The regional development prospects were revealed through the peat industry development based on the regression models built by calculating the elasticity coefficients.
\end{abstract}

Keywords: Russia, peat industry, region, sustainable development, economic efficiency, Khanty-Mansi Autonomous Area

DOI: http://dx.doi.org/10.15549/jeecar.v8i2.694

\section{INTRODUCTION}

Globally, peat has been recognized as a renewable resource. According to recent scientific expert assessments, it is crucial to the world's climate change impacts because peatlands contain more carbon than all forest ecosystems together (United Nations Framework Convention on Climate Change, 2021). In current conditions, the peat industry in Russia, which for decades was an integral component of the country's fuel and energy balance, has virtually died out - until 2016, the volume of peat production in Russia averaged 1 million tons per year (Dprom.online, 2021). At the same time, according to the latest expert assessments, Russia contains more than $40 \%$ of the world's peat reserves (175 billion tons) (Litvinenko, 2020). At the same time, the annual growth of peat reserves in the country is about 252 million tons, and this is several times more than the volume of modern mining (Analytical Center under the Government of the Russian Federation, 2014).

In Russia, peat is not on the official list of renewable energy sources. Still, it can be considered such due to its rapid renewal (Analytical Center under the Government of the Russian Federation, 2014). Therefore, the 
importance of peat for the country's economy was reconsidered in 2009 by its inclusion in the energy strategy for the period up to 2030 , which recognized peat as one of the strategic essential energy sources for thermal power plants (Ministry of Energy of the Russian Federation, 2021). A strategic objective was set to increase the share of peat energy in Russia's fuel segment from $1-2 \%$ to $8-10 \%$ by 2030 (Ministry of Energy of the Russian Federation, 2021) (today's level is 0.03\% (Dprom.online, 2021). For 2016-2019, the government-subsidized costs for connection to electric networks and a guaranteed energy sales outlet through local grid companies (Federal State Statistics Service, 2021). However, in 2020, a project was approved for ending state support for peat-fired power plants due to their inability to compete with renewable energy sources (The State Duma, 2020). Several plants in the Vladimir region, two in the Kirov region, and one more in the Kostroma region operate on bio-organics in Russia. The introduction of new amendments to the legislation has necessitated solving the issue of support for peat-based power producers locally.

Nevertheless, according to the latest Busines Stat data for 2015-2019, peat mining in Russia has increased slightly by $39.1 \%$, from 1.01 to 1.41 million tons (Busines Stat, 2020). The positive trend is the increased demand for peat consumption on the part of agriculture $(70.6 \%$ or 298.3 thousand tons), which is actively supported by the state within the import substitution strategy over recent years and characterized by the rapid growth development (Busines Stat, 2020). At the same time, the volume of fuel peat production shows a downward trend. In 2015-2019, the production of fuel milled peat decreased by $28.6 \%$ (or by 131.2 thousand tons by volume), sod peat - by $3.1 \%$ (by 0.6 thousand tons), peat bricks and semi-bricks - by $37.1 \%$ (by 16.1 thousand tons) (Busines Stat, 2020). It is difficult to argue about the peat economic efficiency as a fuel because it depends on many factors, but peat can be used efficiently in various areas of economic activity (United Nations, 2018; Dafeng et al., 2019).

On the other hand, peat is a renewable resource - the development of bogs and the peat accumulation is constant, so its rational use will achieve a significant economic effect while minimizing damage to the ecological system (Grzybowski \& Glińska-Lewczuk, 2020). Nevertheless, peat fires in Russia since 2009 and which till now create considerable economic damage to the country were caused precisely by the abandonment of peat territories that provoke potential threats (Sirin et al., 2020). This indicates the need to form the priorities for the peat industry development at the regional level to achieve sustainable development (Abid et al., 2019). There is an urgent need to develop a methodological apparatus to assess the efficiency of peat usage as a factor of sustainable development of the region or administrative unit. This apparatus will make it possible to justify the volume and strategy of the peat industry development. Therefore, this study substantiated the indicators characterizing the region's sustainable development on the example of the KhMAA of Russia. The nature of the relationship between three subsystems of the regional sustainable development and the peat industry development in the region's districts was determined. The potential of sustainable regional development through the peat industry proliferation is argued using quantitative assessments.

The obtained results can serve as a basis for determining the strategic objectives of sustainable regional development, taking into account a balanced assessment of the efficient use of local peat reserves.

\section{LITERATURE REVIEW}

Today, there are few scientific works on the assessment of economic efficiency and feasibility of peat usage and peat industry development in modern scientific literature. Nevertheless, many scientists are still developing in this direction (Lempinen, 2019; Mugerwa et al., 2019; Buschmann et al., 2020). The analysis of scientific literature, which is devoted to the study of economic efficiency of the peat industry, testified that many works considered this problem in terms of the historical development of the peat industry in various countries and its transformation in the period of scientific and technological progress (Lempinen, 2019). Many works are devoted to the study of peat mining and handling as a factor of increasing the agricultural industry 
profitability (Buschmann et al., 2020; Fadhil et al., 2021) and as an alternative source of local importance at the level of individual regional units (Mugerwa et al., 2019). In general, three main economically profitable directions of peat usage were investigated:

The use of peat in the energy sector to generate heat and electricity (Lempinen, 2019; Mugerwa et al., 2019; Semin et al., 2019b);

The use of peat in the agro-industry as fertilizer, litter, compost, and feed additives, and more (Buschmann et al., 2020);

The use of peat in various aspects of socioeconomic development, including industrial (to produce activated carbon, wax, rubber), medical (for the production of steroids and antibiotics, peat baths and compresses), and other aspects, is economically justified (Marchenko et al., 2020).

Scientists have argued that using peat as an energy source on a large scale, comparable to using fossil hydrocarbons, nuclear power, or hydropower, is hardly possible for many economic and environmental reasons. It applies even to countries with impressive peatlands, peat resources, and growth, on both a per unit area and per capita basis (Lempinen, 2019; Mugerwa et al., 2019; Surya et al., 2020). With the discovery and development of large fossil hydrocarbon deposits, the development of nuclear power, and large-scale hydropower, the competitiveness of peat as a fuel has decreased (Pakere \& Blumberga, 2017; Semin et al., 2019a; Progunova et al., 2019). But on the other hand, within the energy efficiency framework, many scientists justify the feasibility of using peat in heat supply as a regional energy carrier (Juutinen et al., 2019). Especially in depressed regions due to rising gas and coal prices, a return to an alternative energy source may become relevant in the domestic market (Juutinen et al., 2019; Vasiljeva et al., 2019; Karaev et al., 2020a; Chikunov et al., 2018). However, it should focus that indeed this statement about the economic feasibility of using peat as a fuel depends on local conditions: the availability of alternative fuels in the region, climatic conditions, the scale of peat deposits, the distance of peat, and alternative fuel transportation, the availability of appropriate peat mining and processing staff, the potentially possible range of peat usage as fuel and source of electricity (Mugerwa et al., 2019; Pakere \& Blumberga, 2017; Juutinen et al., 2019). The international organization TACIS provided proof of the energy efficiency of local peat usage that due to the increasing demand for peat, its production in the world has increased by $10 \%$ in recent years. In particular, Finland mines 10 million tons annually for energy purposes, which provides $20 \%$ of the country's heat (United States Geological Survey, 2021). Small peat-fueled plants with 2 to 10 MW capacity are common in this country (United States Geological Survey, 2021).

The use of peat as an energy resource is also efficient. Scientists justify the countries with insufficient funds to subsidize and invest in the latest renewable energy technologies, which are expensive and difficult to use in current conditions (Pakere \& Blumberga, 2017). Therefore, if there are large peat reserves, it is advisable to resume the peat mining, make pellets used in local boiler houses, and use it widely until alternative energy becomes economically viable (Sirin et al., 2020).

Indeed, using peat as a source of electricity and heat in regions that contain significant gas and oil reserves is not economically feasible (Karaev et al., 2020b). However, peat use can have socio-economic consequences for rural areas, and this should be considered in a land assessment process that includes future agricultural use of reclaimed wetlands (Sulaiman et al., 2019).

Considering peat only as fuel and fertilizer in modern conditions is inappropriate, and many scientists in their works substantiated the multidimensional effect of the peat industry development, especially concerning the regional economy and its use as a local raw material to ensure sustainable regional development (Tanneberger et al., 2021). The value of peatlands to a healthy environment, soil fertility, biodiversity, freshwater conservation, prevention, and climate change mitigation is undeniable. Today, awareness of the vital role of wetlands and the ecosystem services they provide exists at global, regional, and national levels (Sulaiman et al., 2019). Significant peat reserves in the territory also reduce transportation costs (Juutinen et al., 2019). Deep 
processing of peat produces a wide variety of products and materials useful for agriculture, medicine, construction, chemical industry medicines, sorbents, insulating materials, fodder, and so on (Juutinen et al., 2019). All of this creates conditions for the peat industry development, forming the potential for developing a diversified economy in the regions to ensure their sustainable development. It should be noted that so far in this direction, there are no meaningful, comprehensive studies covering the entire range of problems - from conceptual developments to algorithms for solving practical issues in terms of the importance of the peat industry for the sustainability of regional development (Tanneberger et al., 2021). Thus, the decision of prospects, the economic feasibility of the revival of the peat industry requires an assessment of the objective pros and cons, taking into account the specific historical context in which the country, the region is, taking into account the local conditions and priorities.

\section{METHODOLOGY}

In this study, we used methods of fuzzy sets, principal components, and regression analysis to determine the development potential of the peat industry and its impact on the sustainable development of the regions. The use of fuzzy sets as the primary research method is because sustainable development involves balancing its three components: economic, environmental, and social (Sebestyén et al., 2019). This method made it possible to assess the sustainability and the industry potential on individual components and give an integral assessment, avoiding the situation when excessive values of some indicators compensate for the low ones of others, leading to averaged assessments.

The choice of the KhMAA of the RF as the research base is that $25 \%$ of Russian and $10 \%$ of the world's peat reserves are located in this area (Yugra Development Fund, 2021). The peat resource base of the Khanty-Mansiysk Autonomous Okrug-Yugra includes 192 peat deposits with the total balance reserves of 1.3 billion tons of peat by categories $\mathrm{A}+\mathrm{B}+\mathrm{C} 1+\mathrm{C} 2$ and 2118 peat deposits with full resources of 43.4 billion tons. The peat reserves suitable for the fuel and energy industry have been identified in 65 fields and amount to 0.9 billion tons by categories $\mathrm{A}+\mathrm{B}+\mathrm{C} 1+\mathrm{C} 2$. Currently, there is no peat mining for the fuel and energy industry in the district, and specialized enterprises for peat mining and processing are absent. About 100 thousand tons of peat are mined per year for environmental and agricultural needs (Bulletin of the Subsoil User of the Khanty-Mansiysk Autonomous Area, 2021).

To assess the sustainable development of the region, a set of indicators that characterize the economic, social, and environmental development of the region was used:

- The volume of investment per capita, million rubles;

- The volume of investment per capita, million RUB - Inv,

- The volume of gross regional product per capita, million RUB - GRP;

- The natural growth of the population per 1000 people, people $-N P$,

- Migration growth per 1,000 persons, people - MP,

- $\quad$ The unemployment rate, $\%-U E$;

- $\quad$ The average salary, thousand RUB - Sal;

- Consolidated budget balance per capita, thousand RUB - Budg;

- Index of real average income per capita, $\%$ - InC,

- Consolidated budget expenditures on environmental protection per capita, thousand RUB - Env,

- Consolidated budget expenditures on education per capita, thousand RUB - Ed;

- Consolidated budget expenditures on culture per capita, thousand RUB - Cul;

- Consolidated budget expenditures on physical culture and sports per capita, thousand RUB - Sport.

This set is based on (Sebestyén et al., 2019; Campagnolo et al., 2018). To ensure the comparability of all municipalities in the region that are different in population, we used all indicators on a per capita basis.

Based on the values of these indicators for nine districts of KhMAA (Berezovsky, Beloyarsky, Sovetsky, Oktyabrsky, Kondinsky, 
Khanty-Mansiysky, Nefteyugansky, Surgutsky, Nizhnevartovsky) for 2017-2020, factor analysis by the method of principal components in the STATISTICA 12.0 program was conducted. This stage of the analysis aims to determine the groups of correlated indicators (factors) that characterize the components of the region's sustainable development. Using the method of principal components with the method of fuzzy sets does not lead to distortion of the results due to the different number of indicators. They are used to assess different subgroups, directions, structural components (in this study - sustainable development factors). The development indicators for selected factors are calculated, and on their basis - the integral indicator of sustainable development of the region is established. The use of the principal components method also made it possible to statistically confirm the representativeness of the used set of indicators of sustainable development, for which the percentage of factorization was $87.3 \%$ Exceeding the acceptable level of $80 \%$ indicates the completeness of factorization, hence representing the used set of indicators for assessing the region's sustainable development.

The assessment of the region's sustainable development included the calculation of factors and the integral indicator of sustainable development by the formula:

$$
\begin{aligned}
& I=\sum_{i=1}^{n}\left[\frac{d_{i}}{\sum_{i=1}^{m} d_{i}} \times\left(\lambda_{L} \times \mu_{L i}+\lambda_{M} \times \mu_{M i}+\lambda_{H} \times \mu_{H i}\right)\right] \\
& F_{i}=\sum_{j=1}^{m}\left(w_{j} \times\left(\lambda_{L} \times \mu_{L j}+\lambda_{M} \times \mu_{M j}+\lambda_{H} \times \mu_{H j}\right)\right)
\end{aligned}
$$

where $I$ - the value of the integral indicator of the region's sustainable development;

$F_{i}$ - the value of the $i$-th sustainable development factor;

$d_{i}$ - the percentage of the variance of the $i$-th factor;

$W_{j}$ - the relative importance of the $j$-th indicator, which is a part of the $i$-th factor. When calculating the values of the factors, all indicators have equal importance $\left(W_{1}=W_{2}=W_{m}\right)$;
$\mu_{L}, \quad \mu_{M}, \mu_{H}-$ the probability of assigning a factor/indicator to a low, medium, high level, respectively;

$\lambda_{L}, \lambda_{M}, \lambda_{H}$ - corrective indicators, taking values for indicators and factors-stimulants of regional development of 0.1 for the low, 0.5 for the medium, 0.9 for the high indicator level; for indicators and factors-disincentives -0.1 for the high, 0.5 - for the medium, 0.9 - for the low indicator level;

- $n$ - the number of factors, on which basis the integral indicator of sustainable development is calculated;

- $m$ - the number of indicators on which basis the factor is calculated.

For determining the factors and indicators of sustainable development, the range of values of each indicator in the study sample is divided into five identical intervals, which correspond to the low, medium, high level, and two intermediate levels between them. For the intermediate levels, the probability of assigning indicators to adjacent levels is determined by the formula:

$$
\left\{\begin{array}{l}
\mu_{1}=1-\mu_{2} \\
\mu_{2}=\frac{X-X_{1}}{X_{2}-X_{1}}
\end{array}\right.
$$

where $\mu_{1}$ - the probability of assigning a factor/indicator to the lowest of two adjacent levels;

$\mu_{2}$ - the probability of assigning a factor/indicator to the highest of two adjacent levels;

$X$ - the factor/indicator value;

$X_{1}$ - the maximum value of the factor/indicator, which is the upper limit of the lowest of the two adjacent levels;

$X_{2}$ - the minimum value of the factor/indicator, which is the lower limit of the highest level.

With formulas (1) and (2), the potential for developing the peat industry in the region in the context of the realized and unrealized potential is also determined. As particular indicators, determining the market potential, are used:

1. The supply (production) factors such as natural, labor, financial resources of the region (Megits et al., 2020; Chikunov et al., 2019). 
The indicators of the number of peat deposits by districts of Khanty-Mansiysk Autonomous Area, which constitute the distributed (D.dis) and undistributed fund (D.un), describe the availability of natural resources. These indicators characterize the realized and unrealized, respectively, the potential of the industry.

The index of the economically active population, \% $(E A P)$ and the growth rate of productive forces distribution, \% $(P F)$, which according to (Yugra Development Fund, 2021), is estimated through the change in the number of graduates of professional and higher educational institutions of the respective district, are used among the indicators of labor resources availability. In contrast to the indicators of sustainable development used per capita, these indicators are presented as index values to reflect the dynamics of the region's development. The positive dynamics of the mentioned components develop the potential of the peat mining market due to the growth of the region's labor supply. The actual values of these indicators determine the realized potential. Since these indicators have no limits on the maximum value, the unrealized potential is determined by comparing the actual values of the indicators with the maximum values for the period 2017-2020.

The indicator of investment climate and promotion of competition (Inv.Cl) was used to characterize the availability and accessibility of financial resources. This indicator, according to the methodology of its calculation (Investment Portal of Khanty-Mansiysk Autonomous Okrug Yugra, 2021), is an integral value and includes indicators of the dynamics of attracted investments in the region, the efficiency of organizational mechanisms and the quality of information support to investors, development of small and medium enterprises, business climate and competition development. It is an indicator of investment attractiveness and, consequently, of the possibility of attracting financial resources for the development of the peat industry in the region (Jelnova, 2013). The actual values of this indicator characterize the realized potential and the gap of actual values with the maximum possible - unrealized one.
2. Factors determining the demand. Peat, as stated earlier, is a raw material for many industries. Therefore, the index of industrial (excluding mining) and agricultural products $(I P)$ was used as demand factors. For the region under study, the primary type of extracted minerals is oil, the growth of which production is a limiting factor to the development of the potential of the peat industry as it is a competing commodity when using peat as a fuel resource (Ponkratov et al., 2020). The growth of production of all other industries (except mining) and agriculture can have a stimulating effect on the development of the peat industry. The indicators of the foreign trade turnover were not used when determining the peat industry's development potential, as peat contribution to foreign trade activity is insignificant and is not reflected in the official statistics. For other commodity groups, the impact of exports and imports is mediated through the product index (IP) (Osipov et al., 2018). The realized and unrealized potential for this component is defined similarly to the labor availability indicator.

The relationship between the indicators of the peat industry potential and the sustainability of regional development has been determined using the Granger causality test. The assessment of the mutual impact nature between the indicators was carried out by building linear regression models; their variables were the indicators of sustainable development of the region $(I)$ and the realized potential (POTr).

When assessing the potential for peat industry development, sustainable development of the region, and the relationship between these indicators, statistical data for nine districts of KhMAA for 2017-2020 (Yugra Development Fund, 2021; Investment Portal of KhantyMansiysk Okrug - Yugra, 2021) were used.

\section{RESULTS}

According to the results of using the principal components method based on the values of indicators of sustainable development of the KhMAA districts, the structure of the factors determining the region's sustainable development was determined. Statistical characteristics of the factors are given in Table 1. The indicator of factor loadings determines 
the composition of the factors. The loadings $\geq \| 0.7 \mid$ are considered significant (Menke, 2018).

Table 1: Factors of sustainable development of the KhMAA districts

\begin{tabular}{|c|c|c|c|}
\hline \multirow{2}{*}{ Factor } & \multirow{2}{*}{$\begin{array}{l}\text { Factor } \\
\text { variance, \% }\end{array}$} & \multicolumn{2}{|c|}{$\begin{array}{l}\text { Significant factor loadings of the indicators } \\
\text { that formed the factor }\end{array}$} \\
\hline & & Indicators & $\begin{array}{l}\text { Values of factor } \\
\text { loading }\end{array}$ \\
\hline \multirow{5}{*}{ Budget factor $(B F)$} & \multirow{5}{*}{25.3} & Budg & 0.79 \\
\hline & & EnV & 0.86 \\
\hline & & $E d$ & 0.91 \\
\hline & & Cul & 0.88 \\
\hline & & Sport & 0.81 \\
\hline \multirow{3}{*}{ Labor market factor $(L M F)$} & \multirow{3}{*}{21.5} & $U E$ & -0.83 \\
\hline & & Sal & 0.92 \\
\hline & & Inc & 0.90 \\
\hline \multirow{2}{*}{ Economic factor $(E F)$} & \multirow{2}{*}{20.6} & $\operatorname{InV}$ & 0.94 \\
\hline & & GRP & 0.85 \\
\hline \multirow{2}{*}{ Demographic factor $(D F)$} & \multirow{2}{*}{19.9} & $N P$ & 0.77 \\
\hline & & $M P$ & 0.86 \\
\hline
\end{tabular}

The structure of sustainable development indicators of the region is represented by:

1) The budget factor, which characterizes the expenditures of the consolidated budget of the district on environmental protection, education, culture, sports, as well as the balance of the consolidated budget. The factor variance was $25.3 \%$;

2) The labor market factor, which reflects the level of unemployment, the level of salary, and the population's real income. The factor variance was $21.5 \%$;

3) The economic factor, which at $20.6 \%$ describes the sustainability of the region's development and characterizes its components such as the volume of investment and the volume of the gross regional product;

4) The demographic factor, which characterizes the natural and migration growth of the region's population. The factor variance was $19.9 \%$.

All indicators (except for $U E$ ) are stimulators in the development of the region. Signs of regional development are an increase in spending on the social sphere (education, culture, sports), environmental protection (growth of budget expenditures) while ensuring budget security as a prospect of regional development, expressed through the indicator of consolidated budget balance. The increase in population income (salary and total income) indicates the growth of social welfare. The increase in the volume of the gross regional product indicates the region's economic development in the current period and the increase in investment (also in the future). Positive natural and migration growth is a factor of the region's development in the future and the indicator of attractiveness of the region for life. The indicator-disincentive of regional development is the unemployment rate $(U E)$. Based on the fact that the factor loading of this indicator has a negative value, and all other indicators have positive values, all factors are defined as stimulators of regional development. The increase in the values of all factors indicates the sustainable development of the region.

Within the selected factors, based on the values of the indicators for the period 20172020 , the ranges of the levels of indicators were determined for KhMAA districts from 2017 to 2020 (Table 2). 
Table 2: Ranges of indicator levels of sustainable development of the KhMAA districts

\begin{tabular}{|l|l|l|l|}
\hline \multirow{2}{*}{ Indicator } & \multicolumn{3}{|c|}{ Level } \\
\cline { 2 - 4 } & \multicolumn{1}{|c|}{$\operatorname{Low}\left(\boldsymbol{\mu}_{L}=1\right)$} & Medium $\left(\boldsymbol{\mu}_{M}=1\right)$ & High $\left(\boldsymbol{\mu}_{H}=\mathbf{1}\right)$ \\
\hline Budg & $\leq 2.96$ & {$[20.39 ; 37.83]$} & $\geq 55.27$ \\
\hline EnV & $\leq 1.93$ & {$[3.73 ; 5.53]$} & $\geq 7.32$ \\
\hline$E d$ & $\leq 286.01$ & {$[552.74 ; 819.47]$} & $\geq 1086.20$ \\
\hline CuI & $\leq 25.48$ & {$[49.24 ; 73.00]$} & $\geq 96.76$ \\
\hline Sport & $\leq 12.87$ & {$[24.87 ; 36.87]$} & $\geq 48.86$ \\
\hline UE & $\leq 0.75$ & {$[1.44 ; 2.14]$} & $\geq 2.83$ \\
\hline Sal & $\leq 63.89$ & {$[70.83 ; 77.76]$} & $\geq 84.70$ \\
\hline Inc & $\leq 103.70$ & {$[108.30 ; 112.90]$} & $\geq 117.50$ \\
\hline InV & $\leq 1.36$ & {$[2.69 ; 4.02]$} & $\geq 5.36$ \\
\hline$G R P$ & $\leq 5.10$ & {$[9.85 ; 14.61]$} & $\geq 19.36$ \\
\hline$N P$ & $\leq-1.63$ & {$[-0.10 ; 1.43]$} & $\geq 2.96$ \\
\hline$M P$ & $\leq-5.27$ & {$[-2.20 ; 0.87]$} & $\geq 3.93$ \\
\hline
\end{tabular}

Provided ranges of levels correspond to the zones of $100 \%$ confidence in the attribution of indicators to low, medium, and high levels. The values of the factors and the integral indicator of sustainable development by KhMAA districts for the period 2017-2020, calculated by the formula (1), are shown in Table 3. For the $U E$ indicator, a disincentive, when calculating the labor market factor value, the correcting indicator $(\lambda)$ took values of 0.1 for the high, 0.5 for the medium, 0.9 for the low indicator level. For all other indicators and all factors, it is opposite: 0.1 for the low, 0.5 for the medium, and 0.9 for the high indicator level.
Table 3 shows that Nizhnevartovsky, KhantyMansiysky, and Surgutsky districts demonstrate the highest level of development. The development of Nizhnevartovsky district in 2017 was at an average level, throughout 20182020 - at an intermediate level between medium and high due to the predominantly high level of budget factor development and the level of growth above average for the economic factor. The lowest level of development for this district is observed in the labor market factor. It is the average level due to the low growth rate of real average per capita income compared to other districts.

Table 3: Values of factors and integral indicator of sustainable development by KhMAA districts for the period 2017-2020

\begin{tabular}{|c|c|c|c|c|c|c|c|c|c|c|c|c|}
\hline \multirow{2}{*}{ pistrict } & \multicolumn{4}{|c|}{ Value } & \multicolumn{4}{|c|}{ Value } & \multicolumn{4}{|c|}{ Value } \\
\hline & 2017 & 2018 & 2019 & 2020 & 2017 & 2018 & 2019 & 2020 & 2017 & 2018 & 2019 & 2020 \\
\hline & \multicolumn{4}{|l|}{$B F$} & \multicolumn{4}{|l|}{$L M F$} & \multicolumn{4}{|l|}{$E F$} \\
\hline Berezovsky & 0.10 & 0.10 & 0.12 & 0.10 & 0.20 & 0.23 & 0.26 & 0.25 & 0.10 & 0.10 & 0.10 & 0.10 \\
\hline \begin{tabular}{|l|} 
Beloyarsky \\
\end{tabular} & 0.10 & 0.15 & 0.21 & 0.10 & 0.33 & 0.35 & 0.37 & 0.37 & 0.12 & 0.16 & 0.20 & 0.10 \\
\hline \begin{tabular}{|l|} 
Sovetsky \\
\end{tabular} & 0.10 & 0.10 & 0.14 & 0.10 & 0.30 & 0.33 & 0.36 & 0.34 & 0.10 & 0.12 & 0.15 & 0.10 \\
\hline Oktyabrsky & 0.15 & 0.18 & 0.16 & 0.10 & 0.23 & 0.24 & 0.29 & 0.23 & 0.14 & 0.19 & 0.26 & 0.10 \\
\hline \begin{tabular}{|l|} 
Kondinsky \\
\end{tabular} & 0.11 & 0.12 & 0.16 & 0.10 & 0.39 & 0.44 & 0.49 & 0.47 & 0.10 & 0.14 & 0.19 & 0.10 \\
\hline \begin{tabular}{|l|} 
Khanty- \\
Mansiysky \\
\end{tabular} & 0.68 & 0.76 & 0.78 & 0.72 & 0.33 & 0.39 & 0.44 & 0.41 & 0.81 & 0.83 & 0.85 & 0.86 \\
\hline \begin{tabular}{|l|} 
Nefteyugansky \\
\end{tabular} & 0.18 & 0.24 & 0.26 & 0.20 & 0.52 & 0.56 & 0.60 & 0.58 & 0.50 & 0.50 & 0.50 & 0.36 \\
\hline \begin{tabular}{|l|} 
Surgutsky \\
\end{tabular} & 0.44 & 0.48 & 0.54 & 0.52 & 0.50 & 0.55 & 0.50 & 0.50 & 0.28 & 0.31 & 0.34 & 0.34 \\
\hline $\begin{array}{l}\text { Nizhnevartovs } \\
\text { ky }\end{array}$ & \begin{tabular}{|l|}
0.71 \\
\end{tabular} & \begin{tabular}{|l|l|}
0.74 \\
\end{tabular} & \begin{tabular}{|l|}
0.79 \\
\end{tabular} & 0.75 & 0.50 & 0.54 & 0.55 & 0.55 & 0.50 & 0.62 & 0.70 & 0.70 \\
\hline
\end{tabular}


Table 3: Continued

\begin{tabular}{|l|l|l|l|l|l|l|l|l|l|}
\hline & \multicolumn{4}{|c|}{$D F$} & \multicolumn{3}{c|}{$I$} & Symbols: \\
\hline Berezovsky & 0.55 & 0.56 & 0.58 & 0.58 & 0.23 & 0.24 & 0.25 & 0.25 & \multirow{2}{*}{ S low level } \\
\hline Beloyarsky & 0.70 & 0.70 & 0.88 & 0.90 & 0.30 & 0.33 & 0.40 & 0.35 \\
\hline Sovetsky & 0.10 & 0.16 & 0.29 & 0.25 & 0.15 & 0.18 & 0.23 & 0.19 \\
\hline Oktyabrsky & 0.30 & 0.36 & 0.39 & 0.37 & 0.20 & 0.24 & 0.27 & 0.20 \\
\hline Kondinsky & 0.20 & 0.31 & 0.33 & 0.30 & 0.20 & 0.25 & 0.29 & 0.24 \\
\hline $\begin{array}{l}\text { Khanty- } \\
\text { Mansiysky }\end{array}$ & 0.12 & 0.13 & 0.15 & 0.13 & 0.50 & 0.54 & 0.57 & 0.53 \\
\hline Nefteyugansky & 0.50 & 0.50 & 0.50 & 0.50 & 0.41 & 0.44 & 0.46 & 0.40 \\
\hline Surgutsky & 0.50 & 0.50 & 0.50 & 0.50 & 0.43 & 0.46 & 0.47 & 0.47 \\
\hline $\begin{array}{l}\text { Nizhnevartovs } \\
\text { ky }\end{array}$ & 0.50 & 0.55 & 0.61 & 0.54 & 0.56 & 0.62 & 0.67 & 0.64 \\
\hline
\end{tabular}

The Khanty-Mansiysky district has a high level of development of the economic factor during 2017-2020, high and intermediate between an average and high level of development of the budget factor. The disincentive for the region's development is the low level of development of the demographic factor and the below average, except for 2019, labor market factor mainly due to a negative balance of natural and migration growth and a low, compared to other regions, level of average wages. The value of the integral indicator of sustainable development of the district was in the range of $0.50-0.57$. It corresponds to the average level.

For the Surgutsky district, the integral indicator of sustainable development was also at the average level during the study period. A positive impact on the region's development has the budget factor, the labor market factor, and the demographic factor, which was at an average level.

The lowest values of the integral indicator of sustainable development are in Berezovsky and Sovetsky districts (low level throughout 20172020), Oktyabrskyand Kondinsky districts (low level throughout 2017-2018, 2020).

Calculated using the method of fuzzy sets, the indicators of the development potential of the region's peat industry are shown in Table 4.

Table 4: The integral indicator values of the realized and unrealized development potential of the peat industry of KhMAA districts for the period 2017-2020

\begin{tabular}{|l|c|c|c|c|c|c|c|c|}
\hline \multirow{2}{*}{ District } & \multicolumn{3}{|l|}{ Indicator of realized potential } & \multicolumn{4}{|c|}{ Indicator of unrealized potential } \\
\cline { 2 - 12 } & $\mathbf{2 0 1 7}$ & $\mathbf{2 0 1 8}$ & $\mathbf{2 0 1 9}$ & $\mathbf{2 0 2 0}$ & $\mathbf{2 0 1 7}$ & $\mathbf{2 0 1 8}$ & $\mathbf{2 0 1 9}$ & $\mathbf{2 0 2 0}$ \\
\hline Berezovsky & 0.20 & 0.24 & 0.26 & 0.22 & 0.70 & 0.66 & 0.64 & 0.68 \\
\hline Beloyarsky & 0.13 & 0.16 & 0.18 & 0.16 & 0.77 & 0.74 & 0.72 & 0.74 \\
\hline Sovetsky & 0.21 & 0.24 & 0.26 & 0.26 & 0.69 & 0.66 & 0.64 & 0.64 \\
\hline Oktyabrsky & 0.14 & 0.17 & 0.19 & 0.18 & 0.76 & 0.73 & 0.71 & 0.72 \\
\hline Kondinsky & 0.21 & 0.22 & 0.26 & 0.24 & 0.69 & 0.68 & 0.64 & 0.66 \\
\hline $\begin{array}{c}\text { Khanty- } \\
\text { Mansiysky }\end{array}$ & 0.30 & 0.32 & 0.35 & & & & & \\
\hline Nefteyugansky & 0.31 & 0.35 & 0.37 & 0.35 & 0.59 & 0.55 & 0.53 & 0.55 \\
\hline Surgutsky & 0.68 & 0.70 & 0.74 & 0.71 & 0.22 & 0.20 & 0.16 & 0.19 \\
\hline Nizhnevartovsky & 0.33 & 0.37 & 0.39 & 0.34 & 0.57 & 0.53 & 0.51 & 0.56 \\
\hline
\end{tabular}

Despite Busines Stat's optimistic forecasts regarding the growth of Russia's aggregate peat production over 2020-2024 (Busines Stat, 2020), the results show a decrease in the realized 
potential of KhMAA and an increase in the unrealized potential in 2020 (Busines Stat, 2020) due to a decrease in the index of industrial and agricultural production, investment attractiveness of the region due to the Covid-19 pandemic (Vasiljeva et al., 2020). The downward dynamics of these indicators are evidence of the decline in demand for peat due to reduced production in all sectors of the economy and supply due to reduced opportunities to attract financial resources for the mining and processing of peat.

Peat mining is the most developed in the Surgutsky district, where 31 peat deposits are being developed; it is $72 \%$ of the distributed fund of KhMAA. Other 27 deposits belong to the undistributed fund. In addition to the availability of natural resources, the district is characterized by an increase in the economically active population, the index of distribution of productive forces, which indicates the availability of labor resources. Among other districts, this district has the highest indicator of investment climate and promotion of competition. The realized potential of the Surgutsky district is $78.9 \%$, the unrealized one is $21.1 \%$. In other districts, the potential for peat industry development by the results of 2020 is realized by $17.8-38.9 \%$.

The stationarity of the industry development potential (POTr) indicators and the integral indicator of sustainable development (I) made it possible to use the Granger causality test to determine the causal relationship between the indicators. Application of the test showed that statistically significant at a significance level of 0.05 is a two-way relationship between the indicators of realized potential and sustainable development of the region. The impact of the indicator of sustainable development on the realized potential is achieved without a time lag. It can be explained by the fact that the decline in the level of the region development (primarily the budget and economic factors) leads to a decrease in production volumes, investment attractiveness of the region and can suspend peat harvesting in consequence of the lack of financial resources. In the opposite direction, the mutual impact between the indicators occurs with a lag of 2 periods ( 2 years). The nature of the impact between the indicators is determined based on the constructed linear regression models (Table 5).

Table 5: Regression models of interdependence between indicators of sustainable development and the realized potential for development of the peat industry of KhMAA

\begin{tabular}{|c|c|c|c|c|}
\hline Direction of causality & Model & F- test & t-test & Elasticity coefficient, \% \\
\hline$P O T r \rightarrow I$ & $I=0.63 \times P O T r(-2)+0.20$ & 6.98 & 2.64 & 0.47 \\
\hline$I \rightarrow P O T r$ & $P O T r=0.52 \times I+0.11$ & 17.62 & 4.20 & 0.63 \\
\hline
\end{tabular}

The empirical values of the F-test and t-test, presented in Table 5, evidence the adequacy of the built models. These values exceed the critical values at a significance level of 0.05 . These are 4.49 for the F-test, 2.12 for the t-test from the model $I=f(P O T r(-2))$, and 4.12 for the Ftest, 2.03 for the t-test from the model $P O T r=f(I)$.

The built models evidenced a two-way direct impact between the indicators of the realized potential of the peat market and sustainable development of KhMAA (in the context of its districts). The calculated elasticity coefficients indicate that the growth of indicator $I$ by $1 \%$ leads to the growth of POTr by $0.63 \%$. The growth of the POTr indicator by $1 \%$ leads to the growth of $I$ by $0.47 \%$.

\section{DISCUSSION}

This study was devoted to developing a methodological approach that reveals the nature of the interaction between the development of the peat industry and regional sustainability on the example of KhMAA of Russia through an empirical assessment. This study will be useful in practice for the implementation of diagnostics of the necessity of peat industry development in appropriate volumes taking into account the potential and current state of economic, social, and environmental regional conditions. A distinctive feature of the proposed approach is the comprehensiveness of the formed system of 
indicators. It characterizes the sustainable development of the region given the existing peat reserves and the specifics of its use in contrast to the studies of economic efficiency of the peat industry in the context of individual components of sustainable development (Tanneberger et al., 2021) or on the example of a respective industry (Pakere \& Blumberga, 2017; Juutinen et al., 2019) or enterprise (Lempinen, 2019). A balanced assessment of the peat industry development's positive or negative impact will determine the extent of peat usage in various sectors of the regional economy and reduce the level of uncontrolled ignition of peatlands. It will provide identification of priorities for investment and innovative development of the peat industry. In turn, it will make it possible to obtain products with high added value and consider peat no longer as an archaic and inefficient fuel but as a source of some high-tech and cost-effective products (Degtyareva et al., 2013).

The study results show that even though peat is a source of energy and heat in Russia today, it is not efficient to use it at the national level. However, in regions rich in alternative energy sources as KhMAA, the use of peat primarily in agriculture has a significant positive impact on the sustainable development potential of the region as a whole and in the context of certain districts of the autonomous area. Due to unrealized potential due to the development of peat deposits that belong to the undistributed fund, it is possible to increase the indicator of sustainable energy development at Sovetsky district by $13.9 \%$, Oktyabrsky - $10.3 \%$, KhantyMansiysky - $0.4 \%$, Nefteyugansky - 2.5\%, Surgutsky $-7.8 \%$, and Nizhnevartovsky $-12.1 \%$. For Berezovsky, Beloyarsky, and Kondinsky districts, the development of the undistributed fund, which amounts to 7,1 , and 7 peat deposits, respectively, will not lead to statistically significant changes in the level of sustainable development of the districts. Based on the results of the empirical study, it can be stated that in the short term, the most important direction of the peat industry transformation in the KhMAA with the transition to a model of sustainable development should be seen as its complete restructuring. Its basic idea is that resource- and energy-intensive industries should be replaced by knowledge-intensive, high-tech, automated production.

For the peat industry is relevant the development of new types of products based on the deep processing of peat raw materials, the search for new opportunities for the peat use as an organic material for processing and obtaining organic and organic-mineral fertilizers, biostimulants, growth substances, bacterial preparations, fodder yeasts and carbohydrate feed additives, a wide range of products for greenhouse and food gardens, absorbents of harmful substances from gas and water environments, wood dyes, chemical fibers, textiles and leathers, and so on. Management of the sustainable development process of the peat industry and the positive impact on the sustainability of the region should be carried out based on the results of scientific research. The task of science, in this case, is to develop new resource-saving technologies, search for economic incentives, promoting cleaner production and environmental management.

The study has some limitations. Since not all of the indicators of sustainable development and potential of the peat industry used in the study have minimum and maximum limits, the indicators are determined based on their actual values for 2017-2020 by KhMAA districts. This limits the use of deterministic ranges of values of indicator levels for other regions, industries, and countries. A similar limitation is associated with the factors of sustainable development, the list and composition of which may differ depending on the region of the study. Therefore, it is necessary to recalculate the levels of indicators and factors for other regions and areas of use. But the very methodology of assessing the potential of the peat industry development in the context of its impact on the level of sustainable development of the region is universal.

\section{REFERENCES}

Abid, N.M., Saeed, A.A., \& Al-Beyaty, S.F.G. (2019). Trends in the physical and social urban form: policy-making and natural sustainable development dialectics. Journal of Southwest Jiaotong University, 54(6). https://doi.org/10.35741/issn.02582724.54.6.57 
Analytical Center under the Government of the Russian Federation. (2014). Does peat have a future in Russia's energy sector? Energy Bulletin, 17, 20-27.

Bulletin of the Subsoil User of the KhantyMansiysk Autonomous Area. (2021). Mining and use of lignite and peat. http://www.oilnews.ru/23-23/7-dobycha-iispolzovanie-buryx-uglej-i-torfa/

Buschmann, C., Röder, N., Berglund, K., Berglund, Ö., Lærke, P.E., Maddison, M., Mander, Ü., Myllys, M., Osterburg, B., \& van den Akker, J.J.H. (2020). Perspectives on agriculturally used drained peat soils: comparison of the socio-economic and ecological business environments of six European regions. Land Use Policy, 90, 104181. https://doi.org/10.1016/j.landusepol.2019.1 04181

Busines Stat. (2020). Analysis of the peat market in Russia in 2015-2019, assessment of the coronavirus impact, and forecast for 20202024. https://marketing.rbc.ru/research/issue/553 $73 /$

Campagnolo, L., Carraro, C., Eboli, F., Farnia, L., Parrado, R., \& Pierfederici, R. (2018). The exante evaluation of achieving sustainable development goals. Social Indicators Research, 136, 73-116. https://doi.org/10.1007/s11205-017-1572-X

Chikunov, S.O., Gutsunuk, O.N., Ivleva, M.I., Elyakova, I.D., Nikolaeva, I.V., \& Maramygin, M.S. (2018). Improving the economic performance of Russia's energy system based on the development of alternative energy sources. International Journal of Energy Economics and Policy, 8(6), 382-391. https://doi.org/10.32479/ijeep.7025

Chikunov, S.O., Ponkratov, V.V., Sokolov, A.A., Pozdnyaev, A.S., Osinovskaya, I.V., \& Ivleva, M.I. (2019). Financial risks of Russian oil companies in conditions of volatility of global oil prices. International Journal of Energy Economics and Policy, 9(3), 18-29. https://doi.org/10.32479/ijeep.7358

Dafeng, S., Zongkun, L., Xiaohua, Z., Junkai, Z., Renhuan, J., \& Zhiru, L. (2019). Multiobjective optimization method of fuel cell hybrid energy system. Journal of Hunan
University Natural Sciences, 46(10), 46-53. http://jonuns.com/index.php/journal/article /view/349

Degtyareva, I., Marjina, A., \& Shalina, O. (2013). The influence of state on the innovative processes. Journal of Contemporary Economics Issues, 1. https://doi.org/10.24194/11313

Dprom.online. (2021). An endangered species. How peat heating was abandoned in Russia. https://dprom.online/mtindustry/vymirayus hhij-vid-kak-zabrosili-torfyanuyupromyshlennost/

Fadhil, R., Yusuf, M.Y., Bahri, T.S., Maulana, H., \& Fakhrurrazi. (2021). Agricultural insurance policy development system in Indonesia: a meta-analysis. Journal of Hunan University Natural Sciences, 48(2), 121-132. http://jonuns.com/index.php/journal/article /view/508

Federal State Statistics Service. (2021). https://rosstat.gov.ru/

Grzybowski, M., \& Glińska-Lewczuk, K. (2020). The principal threats to the peatlands habitats, in the continental bioregion of Central Europe - A case study of peatland conservation in Poland. Journal for Nature Conservation, 53, 125778. https://doi.org/10.1016/j.jnc.2019.125778

Investment Portal of Khanty-Mansiysk Autonomous Okrug - Yugra. (2021). https://investugra.ru/about/investmentclimate/municipality/

Jelnova, C. (2013). Analysis of the practice of decision-making in the field of investment policy. Journal of Contemporary Economics Issues, 4. https://doi.org/10.24194/41302

Juutinen, A., Saarimaa, M., Ojanen, P., Sarkkola, S., Haara, A., Karhu, J., Nieminen, M., Minkkinen, K., Penttilä, T., Laatikainen, M., \& Tolvanen, A. (2019). Trade-offs between economic returns, biodiversity, and ecosystem services in the selection of energy peat production sites. Ecosystem Services, 40, 101027. https://doi.org/10.1016/j.ecoser.2019.10102 7

Karaev, A., Ponkratov, V., Masterov, A., Kireeva, E., \& Volkova, M. (2020a). Cross-country analysis of the comparative efficiency of 
government support for coal and lignite production. International Journal of Energy Economics and Policy, 10 5), 220-227. https://doi.org/10.32479/ijeep.9550

Karaev, A.K., Ponkratov, V.V., Masterov, A.I., Pozdnyaev, A.S., \& Kuznetsov, N.V. (2020b). The analysis of the comparative efficiency of state support for natural gas production: the case of some OECD and BRICS countries. Entrepreneurship and Sustainability Issues, 73), 1778-1789.

https://doi.org/10.9770/jesi.2020.7.3(22)

Lempinen, H. (2019). "Barely surviving on a pile of gold": arguing for the case of peat energy in 2010s Finland. Energy Policy, 128, 1-7. https://doi.org/10.1016/j.enpol.2018.12.041

Litvinenko, V. (2020). Scientific and practical studies of raw material issues. London: Taylor \& Francis Group.

Marchenko, O., Solomin, S., Kozlov, A., Shamanskiy, V., \& Donskoy, I. (2020). Economic efficiency assessment of using wood waste in cogeneration plants with multi-stage gasification. Applied Sciences, 10(21), 7600.

https://doi.org/10.3390/app10217600

Megits, N., Neskorodieva, I., \& Schuster, J. (2020). Impact assessment of the COVID19 on trade between Eastern Europe and China. Journal of Eastern European and Central Asian Research, 73), 385-399. https://doi.org/10.15549/jeecar.v7i3.579

Menke, W. (2018). Factor analysis. In Geophysical data analysis (pp. 207-222). Academic Press. https://doi.org/10.1016/B978-0-12-8135556.00010-1

Ministry of Energy of the Russian Federation. (2021). The energy strategy for the period up to 2030. https://minenergo.gov.ru/node/15357

Mugerwa, T., Rwabuhungu, D.E., Ehinola, O.A., Uwanyirigira, J., \& Muyizere, D. (2019). Rwanda peat deposits: an alternative to energy sources. Energy Reports, 5, 11511155. https://doi.org/10.1016/j.egyr.2019.08.008

Osipov, G., Karepova, S., Chizhevskaya, E., Gnatyuk, M., Semin, A., \& Mikhayluk, O. (2018). Directions to improve the effectiveness of Russia's energy export policy. International Journal of Energy Economics and Policy, 8(6), 227-239. https://doi.org/10.32479/ijeep.7055

Pakere, I., \& Blumberga, D. (2017). Energy efficiency indicators in peat extraction industry - a case study. Energy Procedia, 113, 143-150. https://doi.org/10.1016/j.egypro.2017.04.04 2

Ponkratov, V., Kuznetsov, N., Bashkirova, N., Volkova, M., Alimova, M., Ivleva, M., Vatutina, L., \& Elyakova, I. (2020). Predictive scenarios of the Russian oil industry; with a discussion on macro and micro dynamics of open innovation in the COVID 19 pandemic. Journal of Open Innovation: Technology, Market, and Complexity, 6(3), 85. https://doi.org/10.3390/joitmc6030085

Progunova, L.V., Trokhova, E.V., \& Milonova, M.V. (2019). Internationalization patterns of BRICS Multinational Enterprises MNEs: how differ from other emerging markets? Espacios, 40(35), 26. https://www.revistaespacios.com/a19v40n3 5/19403526.html

Sebestyén, V., Bulla, M., Rédey, Á., \& Abonyi, J. (2019). Data-driven multilayer complex networks of sustainable development goals. Data in Brief, 25, 104049. https://doi.org/10.1016/j.dib.2019.104049

Semin, A.N., Ponkratov, V.V., Sokolov, A.A., Lenkova, O.V., \& Pozdnyaev, A.S. (2019a). Investigating the competitiveness of the Russian oilfield services market. Industrial Engineering \& Management Systems, 18(3), 563-576. https://doi.org/10.7232/iems.2019.18.3.563

Semin, A.N., Ponkratov, V.V., Levchenko, K.G., Pozdnyaev, A.S., Kuznetsov, N.V., \& Lenkova, O.V. (2019b). Optimization model for the Russian electric power generation structure to reduce energy intensity of the economy. International Journal of Energy Economics and Policy, 9(3), 379-387. https://doi.org/10.32479/ijeep.7552

Sirin, A.A., Medvedeva, M.A., Makarov, D.A., Maslov, A.A., \& Joosten, H. (2020). Multispectral satellite-based monitoring of land cover change and associated fire 
reduction after large-scale peatland rewetting following the 2010 peat fires in Moscow Region (Russia). Ecological Engineering, 158, 106044. https://doi.org/10.1016/j.ecoleng.2020.1060 44

Sulaiman, A.A., Sulaeman, Y., \& Minasny, B. (2019). A framework for the development of wetland for agricultural use in Indonesia. Resources, 8, 34. https://doi.org/10.3390/resources8010034

Surya, B., Syafri, Abubakar, H., Sahban, H., \& Sakti, H.H. (2020). Spatial transformation of new city area: economic, social, and environmental sustainability perspective of Makassar City, Indonesia. Journal of Southwest Jiaotong University, 55(3). https://doi.org/10.35741/issn.02582724.55.3.30

Tanneberger, F., Appulo, L., Ewert, S., Lakner, S., Brolcháin, N.Ó., Peters, J., \& Wichtmann, W. (2021). The power of nature-based solutions: how peatlands can help us to achieve key EU sustainability objectives. Advanced Sustainable Systems, 5(1), 2000146. https://doi.org/10.1002/adsu.202000146

The State Duma. (2020). On introducing amendments to the Federal Law "On the Electric Power Industry" about the exclusion of support measures for the generation of electric power using peat as fuel. https://docs.cntd.ru/document/573249908

United Nations. (2018). International recommendations for energy statistics. https://unstats.un.org/unsd/energy/ires/IRES -web.pdf

United Nations Framework Convention on Climate Change. (2021). Restoring peatlands in Russia. https://unfccc.int/climateaction/momentum-for-change/planetaryhealth/restoring-peatlands-in-russia-irussia
United States Geological Survey. (2021). Peat statistics and information. https://www.usgs.gov/centers/nmic/peatstatistics-and-information

Vasiljeva, M., Neskorodieva, I., Ponkratov, V., Kuznetsov, N., Ivlev, V., Ivleva, M., Maramygin, M., \& Zekiy, A. (2020). A predictive model for assessing the impact of the COVID-19 pandemic on the economies of some Eastern European countries. Journal of Open Innovation: Technology, Market, and Complexity, 6(3), 92. https://doi.org/10.3390/joitmc6030092

Vasiljeva, M.V., Ponkratov, V.V., Kharlamova, E.Y., Kuznetsov, N.V., Maramygin, M.S., \& Volkova, M.V. (2019). Problems and prospects of development of the oil exchange market in the Russian Federation. International Journal of Energy Economics and Policy, 9(3), 77-86. https://doi.org/10.32479/ijeep.7378

Yugra Development Fund. (2021). https://fondugra.ru/

\section{ABOUT THE AUTHOR}

Alexander Semin, email: alexandrossemin@yandex.ru

Dr. Alexander Semin is an academician of the Russian Academy of Sciences, Doctor of Sciences (Economics), Professor. He is the Honored Worker of Science and Technology of the Russian Federation (the owner of 22 patents), the Honored Economist of the Russian Federation (2001), the Honored Scientist of the Russian Federation (2010). $\mathrm{He}$ is the founder of a scientific school (he has trained 72 Candidates of Sciences (Economics) and 17 Doctors of Sciences). Mr. Semin is a prominent Russian scientist in the field of methodology, methods, and practice of researching the regional economy and developing regional agri-food policy. 